\title{
Religious Mahbär in Ethiopia: Ritual Elements, Dynamics, and Challenges
}

\author{
Anne Britt Flemmen \\ Department of Sociology, Political Science and Community Planning, \\ UiT The Arctic University of Norway, Tromsø, Norway \\ anne.britt.flemmen@uit.no

\section{Mulumebet Zenebe} \\ Center for Gender Studies, College of Development Studies, \\ Addis Ababa University, Ethiopia \\ muluzen@yahoo.com
}

\begin{abstract}
This article explores the religious association mahbär, also called tsïwwa, in Ethiopia. Data from lay practitioners as well as priests show that religious mahbär has many religious as well as social functions. It is a ritual with long traditions in the Ethiopian Orthodox Täwahedo Church. The authors show that what characterizes mahbär as a ritual is its unusual richness, complexity, multifunctionality and flexibility. By placing it within the Ethiopian religious context and the present development, the authors discuss why religious mahbär is in decline despite its multiple functions, flexibility, and support from the Ethiopian Orthodox Täwahïdo Church. In difficult economic times one would expect traditional rituals such as mahbär to become more important to people, and hence to be strengthened, but this does not seem to be the case here. In the authors' view, three factors are pushing this decline: economic challenges, time constraints, and member recruitment.
\end{abstract}

\section{Keywords}

religious association - Ethiopian Orthodox Täwahïdo Christian - mahbär - tsïwwa commemoration - zïkï - gender - modernization 


\section{Introduction}

In many parts of Ethiopia, especially among Ethiopian Orthodox Täwahïdo Christians, it is customary to have spiritual gatherings. The most important association organized by lay people is referred to as mahbär, also called tsïwwa. ${ }^{1}$ In a religious mahbär ${ }^{2}$ members honor the saints by gathering at a member's house on a saint's day each month, with a rotating host providing food and drinks for the guests (Pankhurst and Endreas 1958). Among the indigenous associations in Ethiopia, mahbär is the least studied. Several research works discuss mahbär together with associations such as iddir (burial associations) and equb (savings associations) (Alula and Damen 2007; Dessalegn 2008; Levine 1965; Korten with Korten 1972; Pankhurst and Endreas 1958). These studies sketch the main functions of the associations without showing in detail how they are practiced in people's everyday lives, or placing them within the Ethiopian religious context.

Ancel (2005) provides a recent and rich source of linguistic, historical, and ethnographic knowledge about mahbär that compares the two religious associations mahbär and sänbäte. Ancel underlines its influence in both rural and urban areas: "To be a member of these associations is a sign of an important social status in the parish community and the reality of both mahbär and sänbäte shows the existence of a way of dialogue between the Church and the faithful" (Ancel 2005, 111). As a religious fraternal association mahbär is reputed to have existed in Ethiopia for hundreds of years (Encyclopaedia Aethiopica vol. 3 2007). As a religious brother- and sisterhood, mahbär has many similarities with sänbäte (Encyclopaedia Aethiopica vol. 4 2010; Ancel 2005). One main difference is that sänbäte is celebrated within the church compound and not in people's homes. Ancel's study is based on a survey in Debre Markos, but the article does not make it clear whether the respondents are both lay people and clergy, and whether both sexes are represented. Research by Marcus (2001) and Pankhurst (1992) are among the few studies that include information about how women practice mahbär as part of their everyday lives. While they find that in rural areas mahbär are strictly gender segregated and single sexed, we find that it is not uncommon to find mixed-gender mahbär in urban areas. In his study Getachew (1998) analyzes mahbär in its own right by exploring the associations' potential for supporting rural-development initiatives. The present article builds on and supplements this existing work by focusing on gender and urban areas. Its particular contribution is analyzing religious mahbär as a ritual and discussing its place in current Ethiopian society.

The article's overall aim is to discuss why membership in religious mahbär seems to be declining despite its multiple functions and flexibility. We discuss this by taking as our starting point how mahbär is practiced in people's 
everyday lives. Furthermore, we situate it in the web of connections of which the ritual is a part. After locating mahbär within the religious context of Ethiopia and within the Ethiopian Orthodox Täwahïdo Church, we then describe the elements and dynamics of the ritual, and analyze the different factors that make mahbär important to Orthodox Christians as well as the factors pushing people away from it. We problematize and discuss how to understand the declining popularity of this particular indigenous association. As we see it, three factors are pushing this decline: economic challenges, time constraints, and member recruitment.

\section{Framing Religious Mahbär}

\section{The Religious Context of Ethiopia}

Ethiopian Orthodox Christians are known for their deep religiosity. Most people's daily lives are linked to church life, and follow the rhythms of fasting, praying, and attending church, especially on the numerous festivals that rule the calendar (Molvaer 1980; Chaillot 2002; Messay 1999). Not all Orthodox Christians attend church on a regular basis but they do celebrate the festivals, either in church or at home. Christianity, Islam, and animism have exerted much influence in the development of diverse cultural traits. Although both Christianity and Islam are widely followed, Orthodox Christianity was the 'state' religion. Following religious rules and rituals is considered appropriate and sometimes mandatory for Orthodox Christians in order to fit into the social system (Bahiru 2002).

If we look at the distribution of followers between the different religious groups as recorded in the national census from 1984 to the most recent one in 2007, we see a clear pattern of the Orthodox Täwahïdo Church losing terrain, particularly in relation to Protestants. A decline is clearly evident, from 54 percent Orthodox Christians in 1984 to 43.5 percent in 2007. While the share of Muslims remains constant with a change from 32.9 in 1984 to 33.9 percent in 2007, the number of Protestants ${ }^{3}$ has increased from 5.48 percent in 1974 to 18.5 percent in 2007 (CSA 2011). These numbers indicate that the Orthodox Täwahïdo Church is under pressure, particularly from Protestants. Abbink (2003) identifies the more-competitive religious environment as a result of 'transnational' religious challenges. Externally supported missionary educational institutions as well as Islamic movements and groups financed from the outside will have consequences:

It will tend to make the EOc [Ethiopian Orthodox Church] lose much of its historical attitude of condoning ... other forms of religious expression 
because it will be forced to much more assert itself. In general, local religious identities and expressions - especially in the context of contested ethno federal nation-building in Ethiopia-will change in the light of such transnational connections.

ABBINK 2003, 4

The Orthodox Christians we talked to tended to be more skeptical toward Protestants than toward Muslims. They viewed Islam as a religion with a long history in Ethiopia, while Protestantism does not. Protestants are considered newcomers or mät'e, as the Ethiopians term it, implying that Protestantism comes from the outside and is not 'inherently' Ethiopian.

Karbo (2013) assesses that Ethiopia faces a major challenge in managing the diversity of religion and ethnicity. The conflict among religions, between religions and the state, and within religions has intensified.

\section{The Ethiopian Orthodox Täwahïdo Church}

The Ethiopian Orthodox Täwahïdo Church is the oldest national church in Africa and has a long history. Even though Ethiopia follows the main beliefs and rituals of Orthodox Christianity, it has a strong native flavor with significant Judaic influences (Pankhurst 1992; Ullendorff 1965). The church is also known by its name 'Täwahïdo' (oneness). For most of its history the Ethiopian Orthodox Täwahïdo Church has been isolated from mainstream Christianity in Europe. First, the Roman Catholic and Eastern Orthodox churches both rejected the Ethiopian Täwahïdo Church's theology at the Council of Chalcedon in 415 A.D. Second, it was separated from Europe politically and geographically by the Muslim conquests in North Africa in the seventh and eighth centuries. This resulted in the development of unique practices and rituals, and in possessing a biblical canon that differs from that of both Catholic and Protestant churches. When a church is threatened, a general understanding is that it tends to harden its patterns in an effort to maintain its identity and seeks to emphasize its distinctive forms, rituals, and dogma. According to Berhanu (2000), this principle applies especially to the Ethiopian tradition.

\section{Methodology}

In exploring how people practice religious mahbär, we employed a qualitative research methodology. We conducted semistructured interviews with nineteen women and eleven men. All were mahbär members from Arada and Kirkos, which are subcities in Addis Ababa, and mahbär members from Šašämäne in 
the Oromia region. These interviews were conducted mainly between 2008 and 2010. Some follow-up interviews were conducted in 2014. The interviewees varied in age from approximately eighteen to 75 years old, and had varied ethnicities-Amhara, Oromo, Gurage, Tigre, and mixed. Their socioeconomic backgrounds ranged from petty traders and daily laborers to housewives and government employees. We interviewed the leaders of the associations about the division of labor in the association and how it is organized and managed. We approached the associations from two angles; initially via its individual members and later at the level of the association itself through the leaders and the clergy. In addition to the interviews, we accompanied some of the interviewees to their mahbär to participate in meetings and gain in-depth information about how the rituals are performed and how the association supports its members. All the mahbär members interviewed were Orthodox Christians.

We interviewed several religious leaders about the role of religious mahbär in the different religions and parts of Ethiopia, including two Orthodox priests, a secretary at an Orthodox Sunday school, two Protestant leaders, and two Muslim elders. We knew from a previous study (Flemmen 2008) that at least some Muslims and Protestants in Addis Ababa participated in iddir, so we wanted to explore whether mahbär was also common among Muslims and Protestants in Ethiopia. We found that the Muslims and Protestants ${ }^{4}$ did not practice mahbär and so they were excluded from the analysis.

We purposefully selected the areas Arat Kilo and Qera in Addis Ababa for interviews because they are old, multiethnic areas with residents from varied social groups. We chose Šašämäne in order to get empirical data from an Oromia region and an urban area outside of the capital. The interviewees here were from several congregations. We believe that the selected areas jointly cover a variety of ways of practicing religious mahbär in urban areas of Ethiopia.

As for our authorial voices, as a team comprised of one native Ethiopian and one Norwegian researcher, we had the benefit of insight into Ethiopian culture, language and customs as well as an outsider's view that prevented us from taking too much insider knowledge for granted.

\section{Elements and Dynamics of the Ritual}

Since there is little available research on mahbär and how it is practiced, we feel it is important to describe the setting of a meeting. Constructing an example based on our empirical data ${ }^{5}$ allows us to make the rituals' choreography explicit. 
A bed of grass is spread on the living room floor. Wz. Almaz, ${ }^{6}$ the host, has been busy checking that everything is in order before the members of her Maryam ${ }^{7}$ Mahbär arrive. Food and drinks are on the table. At 1:00 p.m., nine members arrive one by one. All the members take off their shoes in respect for Saint Mary before entering the room. Saint Mary's picture is on the wall. The members salute the pot called the tsïwwa ${ }^{8}$ as they greet each other by kissing shoulder to shoulder before sitting down to chat. When the priest, Wz. Alamaz's father confessor, arrives he is ceremonially greeted while each member bows and kisses the four corners of his Coptic cross. He invites them to sit down. They exchange greetings. Everybody rises and the priest leads the prayer and cuts the small bread, the salnaq..$^{9}$ The rest of the bread is distributed for the members by the leader, the Muse, ${ }^{10}$ and served with qolo (snack made of roasted grain) and a small cup of t'ela ((local home-brewed beer).

Facing the picture of Saint Mary, they bow their heads and pray for the best for their country, their children, and their health. All present wear their nät'äla (white, woven cotton shawl) as is customary in church, covering themselves from head to toe. After singing psalms about Maryam, each member rises, faces the other members, and says, 'Please forgive me if I offended you, knowingly or unknowingly'. The Muse calls the attention of the members by saying: 'I've been informed that two of our members had a disagreement. Drinking the same tsïwwa we should not have disagreement between us, so I ask you to forgive each other'. The two members stand up and hug each other while the priest blesses them.

The main meal is put on the table, a whole ïnğära (round, large pancake $)^{11}$ on a tray. In this setting it is of importance that the ïngära is unbroken to symbolize the unity of their mahbär, the Muse explains to us. The priest stands up and preaches the gospel. After eating the main meal, the members socialize while drinking the local beer, $t a ̈ l l a$, and eating the roasted grain, qolo. Wz. Almaz goes outside to the compound to serve food, drinks, and snacks to waiting beggars. In return, the beggars give Wz. Almaz their blessing.

To mark the end of the meeting, the Muse brings in the large bread, an important part if the ceremony. The central part of the large bread is cut by the priest ${ }^{12}$ to fit into a container, known as a mäsob (basket). The Muse asks 'Manäš Balä Samünt?'/ Who is next? and calls forward the member hosting the next mahbär meeting. Wz. Aster comes forward, kneels down, and receives blessings from the priest for her willingness to host the next meeting. The mäsob is carefully handed over to her. The 
Muse cuts the remaining bread and distributes it to the members for them to take home. Three close friends of Wz. Aster are among the members who accompany her when she carries the mäsob, the picture of Maryam, and the tsïwwa to her home. ${ }^{13} \mathrm{Wz}$. Aster's neighbors and family members are waiting at her home to celebrate the arrival of the tsïwwa. They begin ululating (ililta) when the group enters the house. Wz. Aster takes the bread out of the mäsob, cuts it, and distributes it together with the t'alla in the tsïwwa to the people present. Next month when she is the host, she will rely on them to help her prepare the food and t'alla for the meeting.

This short description serves to illustrate the dynamic of the ritual. There is great variety in how elaborately the religious element is enacted in the different religious mahbär we have studied. The patron saint chosen determines the day for the monthly gatherings. In the Ethiopian Orthodox Täwahïdo Church, almost every day of the month is dedicated to a particular saint. Like the Eastern Orthodox Churches, the Ethiopian Orthodox Täwahïdo Church still uses the Julian calendar.

In attempting to break down the ritual into its elements, we have taken human action and interaction as the starting point. Following Grimes (2014), we identified the ritual's core elements by identifying actions, actors, places, times, objects, languages, and groups. In this context, the term 'groups' includes the collective considerations of the ritual such as its hierarchy, economics, political dimensions, collective agency, and social distinctions (Grimes 2014).

Despite its variations, we see religious mahbär as containing the following core elements:

- the tsïwwa

- the mäsob

- commemoration (zïkïr) of a patron saint

- a muse

- membership

- lay people's homes

- praying

- sharing food and drink

Mahbär as a ritual is the sum of these core elements. ${ }^{14}$ They represent a stylized version that we have found useful in identifying the ritual's constituent 
parts and to see how the components interrelate. In the following discussion we elaborate on and discuss the more-internal as well as collective considerations of the ritual.

\section{Mahbär according to the Ethiopian Orthodox Täwahïdo Church}

An article on tsüwwa in the magazine Hamer published by the Ethiopian Orthodox Täwahïdo Church (1998, states: 'The first Christians used to come together and eat. They used to call this food the "food of love" or "Agape". Later the 5,000 Christians who lived together were not able to come together and eat because they had to disperse to different countries after the death of Stephanos' (our translation from Amharic). The article follows up with this quote from the New Testament:

(44) All the believers were together and had everything in common. (45) They sold property and possessions to give to anyone who had need. (46) Every day they continued to meet together in the temple courts. They broke bread in their homes and ate together with glad and sincere hearts, (47) praising God and enjoying the favor of all the people. And the Lord added to their number daily those who were being saved.

ACTs 2: 44-47, English quote from the New International Version.

Consequently, this article links the practice of religious mahbär to the practices described in the New Testament where the sharing of food and drink is central, as is giving to the needy. The Historical Dictionary of Ethiopia (Prouty and Rosenfeld 1981) and Ancel (2005) claim that the association is inspired by the Last Supper.

According to the priests interviewed, the Ethiopian Orthodox Täwahïdo Church views mahbär as an ancient custom that symbolizes the first founders of the religion. When Jesus Christ was teaching the world about God, he first organized the twelve disciples. The twelve disciples, the 36 kïdusan anïst, ${ }^{15}$ and the 72 ardits $^{16}$ are called 'The 120 family' (Interviewee 16 ). The 120 family is regarded as the first founders of the religion. Mahbär is formed in the name of religion, and each mahbär has a patron saint. Since mahbär is hosted according to the church's rule, people believe that it needs a protector. Consequently, in most mahbär meetings priests are present to pray and bless the food and drinks. In addition to these blessings, the priest also teaches the members about the saint they have chosen to celebrate in the mahbär, and cautions the 
members to refrain from evil deeds. In mahbär life, love, tolerance, and avoiding bad things are considered important (Gorgorios 1982).

From the church's point of view, the mahbär have several functions. One priest (Interviewee 17) explained: (1) people come together and organize to help feed the needy in the name of a saint, regardless of ethnicity, reciprocity, and so on; (2) members help the church; (3) mahbär teaches members religion; and (4) mahbär helps members to be blessed and to develop a good character and tolerance. The priests link the religious functions with the social. One priest (Interviewee 16) explained that today when the whole world is striving to eradicate poverty, he is happy to see that mahbär has been gaining recognition for its contribution toward this end. As an example, he states that just as the brothers in monasteries live together and help each other, the members of a mahbär help each other. For this reason the church attaches great value to mahbär. 'We protect it as one of our antiques. When people outside the church organize themselves in groups to help eradicate poverty, they follow a strategy that the church followed from the outset'. Another priest stated this view in an even-stronger manner: 'One of the manifestations of being Ethiopian is through religious mahbär' (Interviewee 17). This priest establishes mahbär as a symbol of Ethiopian culture, and a symbol of Ethiopian society itself. He seems to feel that to be Ethiopian is to help others, coupled with a strong devotion to the Orthodox Täwahïdo Church.

Priests view mahbär as important not only to the church but also to the community as a whole. It is a place where the community can discuss numerous issues. The priests use mahbär to inform and create awareness of health issues such as HIV/AIDS; some mahbär arrange trips to places of pilgrimage such as Lalibela and Axum. For this reason the church values mahbär as important and useful. The priests are happy to attend mahbär meetings to bless the food and drinks and to encourage further mahbär. If the mahbär members do not share a priest, the host's father confessor will do the blessing and teaching.

Mahbär is a place where the church spreads its message. Since the priest's main role is to serve the people, the church sends priests to the people. As one priest explains:

What makes the [Ethiopian Orthodox Täwahïdo] church special is that in this way it is present in every house. There is no Orthodox Christian without a religious father and the religious father is responsible to the church. All the churches are reporting or answering to the Hagärä Sibkät. ${ }^{17}$ The Hagärä Sibkät is reporting or answering to the Mänbäre Patriarch. ${ }^{18}$ The Mänbäre Patriarch is answering to the Holy Synods. ${ }^{19}$ This strong 
structure is the reason why the Ethiopian Orthodox Church protects itself and our territory.

INTERVIEWEE 16

The priests we talked to link the history and ancient customs of the Ethiopian Orthodox Täwahïdo Church to the needs of present-day society. In this way they make mahbär relevant by reproducing but simultaneously reinterpreting the practice.

Organized around Orthodox Christianity, religious mahbär have an explicit religious and spiritual purpose. As we have seen, the associations are placed outside the church itself; however, they can create links to the church if they choose to, i.e., through the father confessor being present at the meetings, involving the church in making the bylaws for the mahbär, or by establishing a mahbär for the specific purpose of serving the church by providing labor or money for a particular cause. The priest is not a necessary part of the association but works as a kind of conduit to Christ through the holy water and the tsïwwa, the sacred, ritual pot that all members drink from to symbolize their unity. The priests enable and catalyze, but the association is not dependent on the presence of a priest. As Ancel underlines, mahbär and also sänbäte show 'the existence of a way of dialogue between the Church and the faithful' (Ancel 2005, 111).

\section{Factors Ensuring the Popularity of Religious Mahbär}

Why do lay people spend time practicing religious mahbär? Below we show how members describe the importance of the mahbär (the pull factors). Inspired by Bell's (1997) analytical categories, we categorized the most important functions described in our empirical material as: serving God, social networking, information exchange, conflict resolution and reconciliation, entertainment, and social insurance. We now take a closer look at each of these functions.

\section{Serving God}

Joining a mahbär can be experienced as serving God, as expressing gratitude and doing one's duty as a Christian. A particular incident may trigger people to join a mahbär or initiate one. One female interviewee explained that her mahbär responded to a call issued by the famous and controversial Ethiopian monk Bahitawi G/Meskel (Interviewee 1). He called for subae (meditation and prayer) 
at Mïdre Käbd, close to Abuye. The mahbär members traveled to Mïdre Käbd. They saw that the church was on the verge of collapse and decided to form a mahbär with the goal of renovating the church. They discussed how to raise money, and found a mahbär to be a way to organize and perform this responsibility. This story describes a mahbär engaging in one specific, practical task.

Several told stories of children who recovered after long periods of serious illness because of prayers. Women and men described joining mahbär in gratitude. One man explained that when his son became ill the family went to South Africa in search of a cure, but did not succeed. Instead, the man claimed, the child's life was saved by his mother who made a sacrifice in God's name, and by the child drinking holy water from the Trinity Church. After this experience they joined a mahbär. This man became a member to demonstrate his gratitude after receiving what he perceived as God's help (Interviewee 32). Others believe that being a member will help them in the future. One member shared the personal drama that led him to attend a Maryam mahbär:

Saint Mary's history is very special. Her work is very special. I never thought I would be able to stay alive, get married, or have children. I used to drink very heavily. Even when we had collected sacks of sand on donkeys' backs for the church, I wanted people to give me two bottles of aräqe [strong alcoholic drink] rather than food. So on her celebration day, one religious father had prayed on the aräqe and gave it to me to drink. I drank it, and since then I have never drunk aräqe again. If I drank it now I would be sick.

INTERVIEWEE 7

This man joined a Maryam mahbär to show his respect and gratitude to Saint Mary. He believed that all his wishes would be fulfilled through her since she was the Mother of Christ, and that he would obtain more favors by commemorating Saint Mary's day. Several of the interviewees shared stories about miracles they had witnessed that strengthened their religious belief. However, one member took a more psychological approach to this. He compared miracles to the placebo effect:

Even medicine does not cure unless the patient believes in it. Eighty percent is psychological belief. For example, my father was unable to attend his mahbär for financial reasons and hence he was in a crisis. However, I noticed that once he rejoined the mahbär he was all right.

INTERVIEWEE 27 
His father's psychological well-being depended on his connection to his mahbär. According to Bell (1997), ritual acts of offering, exchange, and communion tend to invoke complex relations of mutual interdependency, not only between people but also between humans and the divine.

Helping the needy and providing them with food is an important task for many but not all of the mahbär. This is considered a Christian virtue and duty. Several interviewees explained that the point of a mahbär is to fulfill what is written in Matthew 10:40, feeding the needy whether they are fellow members or outsiders who are less fortunate. A mahbär that fails to support the needy is not considered a mahbär at all, according to one interviewee (Interviewee 34). Consequently, an Orthodox Christian should be a member of a mahbär in order to fulfill his/her duties as a Christian. As we have seen, this is a view supported by priests in the Ethiopian Orthodox Täwahïdo Church. Participation in a mahbär was viewed as part of being a responsible community member. According to one participant, being a member of a mahbär where like-minded individuals come together establishes religious ties with other Christians.

In our religion he/she who respects saints will be respected....We are like-minded people. There is no senseless talk. We study the gospel. Since all of the members have a good understanding of the mission of the mahbär, we help each other in times of difficulty. When we prepare food and drinks, the needy benefit as well.

INTERVIEWEE 22

\section{Social Networking}

Many of our informants stressed that membership in a mahbär is also a membership in a social network. Most members appreciated the opportunity to socialize with people of their respective mahbär. Members meet regularly during various social events. These include not only funerals but also weddings, christenings, and times of childbirth in members' families. Members are expected to support each other during good times and bad.

One interviewee described her relations to other mahbär members:

Our mahbär is love and peace. Even when we quarrel with our family or friends, it is here in the mahbär that we feel good. All the members share my problems. When I feel sad, they know it from my facial expression. The members who live abroad dream about me and ask what happened to me. When my sister and mother passed away, the members encouraged me. We are like a family. We have a sisterly and brotherly relationship. 
Mahbär membership is often equated to being a family. In line with this analogy, members are also expected to stay together when a family member dies. Most members frequently visit the family of the deceased, particularly during the first three or four days. They provide financial or labor support when a family member dies and regularly visit if a member or their family members are ill. One interviewee explained, 'Mahbär members are always with you when you are happy and sad. For instance, when there is sorrow, we spend twelve days together' (Interviewee 1).

Membership comes with a great deal of social obligation toward fellow members as well as their families. According to one interviewee, a female member supported a young man for five years since he was unable to find work (Interviewee 1), providing him with shelter and covering all his expenses until he received the opportunity to go abroad. This seems to be an extreme example of generosity, and is not the norm among the mahbär we contacted. Obligations of this scope represent support for members but can also present a challenge in times of hardship. Associations will do their utmost to retain members since they attach great importance to staying together in order to uphold the social network. 'When a person wants to leave the mahbär, we will ask why. He/she may, for example, give the cost of living as a reason, or he/she may say, "I am getting old and cannot prepare the food and drinks any more". If these are the reasons, we do not oblige them' (Interview 4). They will try to find other ways to allow the members to stay.

All members of the association socialize, irrespective of their gender, but the female members in one mixed mahbär were especially close. They socialized and talked to each other to a greater extent, discussed personal issues outside mahbär meetings, and shared activities. The men, on the other hand, said they tended to go out and drink together, an activity the female members of the mahbär seldom took part in.

The women isolate themselves in a group, but the men do not have a group.... We love each other. Of course, when the women sit in a group they could have something to discuss because of their femininity.... They may do their own private things. We drink. After attending the mahbär we say to each other, 'Let us drink and be happy'. We drink draft beer. We contribute whatever we have. It could be $5^{0}$ or 100 birr. ${ }^{20}$ After we drink, we say goodbye to each other.

INTERVIEWEE 6

Since social networks are such an important part of membership in the association, it seems reasonable that all have a say in the recruitment of new 
members. Accepting new members is a democratic process in which members check the potential newcomer's background, have discussions, and make a joint decision:

People who want to register also come and tell us that they came to join us because they like us, our patron saint, etc. We do not decide on the same day. We check whether there is a member who is not on good terms with him/her. Finally, we would tell him/her our decision at the upcoming meeting.

INTERVIEWEE 4

Mahbär promotes interdependence and mutual coexistence built on trust. As Messing (referred in Korten and Korten 1972) points out, mahbär is a unique organization within the Amhara society in offering this choice of membership.

In urban areas neighbors are often involved in preparations for mahbär meetings. Despite not being members of the association, they may provide help in preparing food and drinks. Involving the neighbors in this way strengthens the relationships in the neighborhood and, as the following interviewee underlines, strengthens the social fabric.

The next host will take the bread that was cut to fit the mäsob [the salilit]. It is big. She will also take qolo and t'älla to her home. Then her neighbors welcome her by making coffee. She will distribute the bread [the salilit] to them. It is known as mmät'ubiš mätačc ['It is now my turn']. If her neighbors are served, they will help her while she prepares her mahbär... It is said: 'Please drink mmät'ubišs'. It is not for the members. We, the members, leave the house and then the neighbors are served.... The invitation [to eat the salilit] helps keep them informed well in advance. It strengthens the social fabric. Our main goal, if it is God's will, is to see people well connected.... If she tells all her neighbors about it, even at the very beginning they will help her. In general, this helps strengthen people helping each other.

INTERVIEWEE 15

In addition to establishing a social network with the other members, in this way mahbär also strengthens the social relationship with the neighbors.

\section{Information Exchange}

While some members are very articulate and explicit about the different social functions of the mahbär, others are more concerned with their own practical 
and immediate use of it. Information exchange is one such use. At the gatherings people share a variety of information about the economy and the cost of living, where to get cheap products, health and illness, or exchanging advice and information about cures, healers, physicians, medicines, and so on. Such information can be of great importance in a society with a high degree of illiteracy. Political issues that cannot be easily discussed in public, such as the relationship between Christianity and Islam, between the Orthodox and Protestants, ethnicity, the government, and elections, are discussed. In addition to such general topics, they share what is happening in the local community or neighborhood; who has died, who is sick, who got married, or who gave birth. Finally, there are also discussions of personal issues and relationships, such as raising children, dealing with teenagers, handling spouses, or maneuvering in marriage conflicts. In this way mahbär constitute an important forum for information gathering, particularly for women. According to Elias (2008), voluntary associations in general are well suited to promoting the social lives of Ethiopian women, mainly because they are formed based on mutual trust and reciprocity.

\section{Conflict Resolution and Reconciliation}

Ritual action facilitates social life. Ritual activities perform social work by forming and establishing social bonds of human community (Bell 1997). These processes of socialization occur when people appropriate common values and categories of knowledge and experiences. Channeling and resolving social conflict is not an unimportant part of these processes. Unsurprisingly, we find that reconciliation and conflict resolution are important functions of mahbär. Since most mahbär members live in the same neighborhood, they come into conflict on various occasions. Particularly in poor neighborhoods such as some we visited, the women are in close contact since they share kitchens and compounds; this can often cause disagreements and conflict. Members bring issues of conflict, mainly among mahbär members, to their monthly meetings to resolve them in that forum. Getachew points out that mahbär provide an effective means of conflict resolution: 'Compared with the government courts, resolving conflicts with the help of mahbär saves people's time and money' (Getachew 1998, 507-508).

Conflict resolution is institutionalized in mahbär. According to our observations, time is allotted for conflict resolution at mahbär meetings and follows specific procedures. The priest or the muse plays a significant role in settling problems between members. At the beginning of the meeting the priest or the muse is informed about any conflicts among members. Each member approaches the priest or the muse and informs them about specific conflicts. 
Before the members start to eat and discuss other matters, time is set aside to ask for the other members' forgiveness. At a Maryam mahbär meeting we observed, each member stood up in front of all the mahbär members and asked for their forgiveness. This includes mistakes that the person recognizes or those of which they have no recollection. Each person uttered the sentence, 'Awïqem bihon balämawoq qasqäyämkuaččhu bbämaryam sïm yïqürta ïndïtadärgulïn ïtäyiqqalähu' (If I offended you, knowingly or unknowingly, please forgive me in the name of Saint Mary). This is both a ritual pardoning as well as a morespecific and personal seeking of forgiveness. One member explained that forgiveness is a major principle in Christianity, and since members are like sisters and brothers they have to forgive each other.

According to one interviewee, harmony and peace are more prevalent among mahbär members than among iddir members. She said this is because mahbär is a religious association and members' fear of God helps them to forgive each other. She asked, 'How could mahbär members fight each other while drinking a tsïwwa, the symbol of unity?' She added that restraining from quarreling (nägär) is important. Gossip is forbidden and members are strongly encouraged to discuss their problems openly. According to Korten and Korten (1972), rules against gossiping or speaking ill about members are common in mahbär. Korten and Korten interprets suppression of conflict as a way of maintaining group solidarity in a context dominated by individualistic hostility. As one interviewee observed, 'Since iddir is all about mourning and helping each other, rumors are more intense in iddir than in mahbär. Since mahbär is about religious belief, and despite the fact that rumors exist in it too, they are not very strong' (Interviewee 15). We note that the interviewee refers to the "fear of God" being the driving force for people forgiving each other.

In some instances the members solve or attempt to solve family problems during mahbär meetings. These are mainly problems between spouses and they are discussed with a selected few of the members. In one of the mahbär we visited, one particular woman played an important role in helping the other women solve their marital problems. The conflicts that the women brought forward included physical violence. This woman had gained the other members' respect for her wisdom over the years. Some of the women even asked her to talk to their spouses.

\section{Entertainment}

Entertainment and social transgressions are also part of mahbär life. Most of the members we interviewed said they eagerly anticipate the monthly meetings because of the enjoyable time they spend with fellow members. One told us that she counts down the days before the meetings. For many members this 
is their only opportunity to have fun with friends and acquaintances. Drinking creates an atmosphere conducive to talking about light and entertaining issues. Interviewees noted that the meetings provided an opportunity to relax and set aside serious life issues that worry them in their everyday lives.

Mahbär members may play tricks on each other for fun. For example, they tie their nät'äla (cotton shawl) together. The joke is that the member is stuck because of the tied nätäla and so she cannot leave the meeting. Normally members like to sit next to those who crack jokes or make others laugh. These jokers are popular members. Some members are very good at cracking jokes including jokes that are normally called 'dirty jokes'. One interviewee observed that the women are curious about sexual matters, and on some occasions women describe personal stories about extramarital affairs (Interviewee 15). She added that there were times when she had to stop some women from telling personal stories that might later damage their marriages and their reputation.

On some occasions the women drink too much, which can lead to conflict with their husbands. Women have experienced physical abuse because their husbands get angry when they get drunk and stay out late at night. For this reason, members try to remind each other to get home before dark. However, since the women enjoy the meetings so much, they often forget to leave early enough.

These aspects of a mahbär meeting are what Bell calls rituals of fasting, feasting, and festivals. In general, these kinds of rituals are larger-scale social events with religious content. They can extend and overlay the religious value system. By deconstructing the routine for a period, these rituals appear to recognize sources of power outside the system (Bell 1997:136). As such, they legitimate and facilitate changes in the system. Rituals of rebellion are considered a subgroup of rituals of fasting, feasting, and festivals, and are common all over the world. As Gluckman points out (1955, in Gilhus and Mikaelsson 2001), these rituals are important even though they very seldom lead to real societal change. By turning hierarchies upside down, women can, for example, make male power visible; they can play out social tensions and conflicts within these settings. The rebellion is temporary and ritual. As transgressions in carnivalesque rituals, they upset hierarchies in very framed and standardized ways. What seems different in religious mahbär is that this upset is less standardized and thus more open to negotiation. The limits of the ritual are more diffuse, and what is acceptable and unacceptable is therefore less clear. Every association negotiates its own terms, making it more open to the members' needs but also more challenging. Some parts of the ritual are more flexible and negotiable than others. 


\section{Social Insurance}

Membership in mahbär can furthermore be understood as a kind of social insurance. We have identified three kinds of social insurance in our material: first to protect the name, second to keep the tradition alive, and third to build reputation and prestige.

Protection of names motivates membership in mahbär. One mother explained that she took the place of her deceased daughter in a Maryam mahbär to keep the daughter's name alive. More often, the child will be the one that succeeds his/her mother; it is considered very important for the daughter or son to ensure that the mother is not forgotten by taking her place in the mahbär. The point is to keep her name alive or "to let her name be called out" (sïm mast'ärrat). In this way the community members remember the mother and the child honors their mother. Raising a child that fulfills such duties reflects well on the mother's social reputation.

It is quite common for family members to take the place of members that have passed away. We understand this as a social obligation. One of the members we interviewed explained that he took his father's place when his father passed away even though the interviewee was only six years old at the time. The members attended his father's $a r b a^{21}$ and sämania. ${ }^{22}$ The father's association is a rural mahbär and members often contribute labor rather than money. If a member dies in the summertime each member will plow for one day in support of the bereaved family. If the death occurs in the winter they participate in sowing his crop. ${ }^{23}$ Over the last 60 years the mahbär has celebrated his father's name. In his absence, the son appoints a person to keep the membership on his behalf.

For some members it is very important that the deceased's name should be kept in the association in which they were members. This means that a son takes his father's place, a father takes his son's place, or a son takes his mother's place; this legacy membership has no restrictions when it comes to the member's gender. A man can replace a woman in a women's mahbär and a woman can replace a man in a mixed mahbär. These practices can be interpreted as keeping the memory alive, but they may also be examples of rituals of affliction.

Being a member of several iddir and mahbär seems to be a way of building one's reputation and prestige (see also Ancel 2005, Korten and Korten 1972), as well as strengthening one's social position and securing one's good name. Membership provides social security and social prestige, and indicates that you are an active member of the community, a responsible person, and a good citizen. Even though iddir is more important to people, being a member of 
mahbär enhances one's credibility. ${ }^{24}$ People often ask about the number of associations they participate in.

Some mahbär have a special history that makes them particularly impressive. One member explained that it was an honor for him to be a member of the same association in which Emperor Melenik II was a member 100 years ago:

It is a great honor for me to attend a mahbär that was attended by Emperor Melenik II. The other thing that makes it special is that although my mother gave us a new pot [a tsïwwa] three times after the original pot was cracked, we are still using the same pot that was used at the time of the emperor. Since it has been cracked it leaks water when it is washed but surprisingly it does not leak the holy t'älla. As a result, we believe it has a great secret in it.

INTERVIEWEE 27

Being a member of this particular mahbär is prestigious for the interviewee and consequently builds his reputation and prestige in the community.

We have now explored the factors that make this particular ritual attractive to its members and to the Ethiopian Orthodox Täwahïdo Church. To sum up, religious mahbär is a ritual that allows the members a great deal of freedom in its practice. According to the stories shared by the members, the most important religious function seems to be serving God by commemorating the patron saint, drinking from the same pot (the tsïwwa) in order to strengthen the bond with fellow religious practitioners, and establishing relationships of sisterhood and brotherhood. The most important social functions identified were creating a social network, exchanging information, conflict resolution and reconciliation, entertainment, and finally social insurance. The ritual can be viewed as a cultural toolbox in which laypeople have great flexibility in adjusting it according to their needs.

\section{Factors Contributing to the Declining Support for Religious Mahbär}

In recent years changes have been observed in religious mahbär. We found that most mahbär have fewer members than in the past. As stated earlier, in our view three factors are pushing this decline: economic challenges, time constraints, and member recruitment. 


\section{Economic Challenges}

For the most part engagement in mahbär seems to be determined by the household's resources. A number of interviewees stated that nowadays it is difficult to uphold a mahbär membership. Many are worried about economic challenges: 'Things have changed. In the old times, there were people who used to attend more than one mahbär. I used to have two mahbär. Currently I have only one' (Interviewee 3). In one Maryam mahbär, only five of the 40 members remained. As we have seen, members can feel forced to leave their mahbär when they cannot afford to prepare the feast for the monthly meetings. According to the interviewees, preparing food and drinks requires a strong financial situation at home. At mahbär meetings neighbors and relatives are sometimes expected to enjoy the food in addition to the members, thereby increasing the number of invitees. For many poor people hosting the meetings and preparing food for the members is expensive enough; adding nonmembers or even a priest to the meeting adds an extra economic burden.

Not all mahbär have priests who attend their meetings on a regular basis. There are many reasons for not having a priest present, but some members believe that they are expected to provide contributions or gifts for the priest or the church in order for a priest to attend. The members view these contributions as important to the church in that they allow it to arrange proper religious celebrations. The contributions can be money, candles, a gabi (a thick woven shawl of cotton), or an umbrella for ritual purposes.

The decision to quit a mahbär is very difficult. Interviews were conducted with members who were about to leave their mahbär. While some feared they would no longer receive religious favors, others were unhappy about losing their friends and social relationships. Had it not been for financial constraints, all would have continued their memberships. Leaving the mahbär was one of the most difficult decisions they had to make in their lives. Some stated that they were afraid that the nation's economic problems would threaten the very existence of religious mahbär and hence the Ethiopian way of life for Orthodox Christians. Others made suggestions as to what should be done to overcome the current challenges:

As for me, it would have been better if we go to the church and do what is appropriate. Though we prepare the food and the drinks, it is us that consume them. Neither Saint Mary nor Saint Michael will come to eat. Rather, it would be good if we pray and help the needy that are the poorest of the poor. I imagine this is what God would welcome very much. For instance, if we prepare t’älla and bread it would cost at least 300-400 birr. 
I would be happy if we omitted all those things and believe in the Arc of the Covenant (Tabot). ${ }^{25}$ I decided many times to leave the mahbär, but they begged me in the name of the ' $t$ sïw wa' to not quit. Nowadays the cost of living is very high, and I am the one who is affected. Had it not been for my sisters' request to not quit the mahbär, I would have helped the poor monks.

INTERVIEWEE 4

This member is referring to the possibility of turning the mahbär into a sänbäte. Although in many ways a sänbäte is equivalent to a mahbär, as previously mentioned, the members of a sänbäte meet in the compound of the church rather than in members' homes. The social obligations are less in a sänbäte since they normally have more members, and they often prepare less food.

One of the priests also addressed the economic challenges when he emphasized, 'The main objective of a mahbär is not eating and drinking together, it is the spiritual relationship'. He reminded us that the Holy Bible states, 'Commence your gifts from clean water' (Interviewee 17). This priest was concerned about the decline in mahbär, which he attributed to the amount of food being served and hence the expense. In our interviews we found that the priests shared the view that people should reduce the amount of money spent on preparing food and drinks for the gatherings in order to enable poor people to participate. Some churches even monitor the amount of food and drinks prepared to make sure that mahbär is not used as a means to show off wealth or social class. Preparing food and deciding which food to serve are topics of negotiation in many of the associations. Although the associations tend to prioritize ïnğära, initially reducing the kinds of wät' they will serve. If that is not inclusive enough, then members may decide to not serve $\ddot{i n g ̆ a ̈ r a ~ a t ~}$ all. Some have decided to only serve qolo, bread, and t'älla and eliminate the ïnğära and wät' (traditional Ethiopian sauce eaten with ̈̈nğära). 'For the last six months, we prepare qolo and bread, if available. If not, we prepare whatever is available. Since things are getting expensive and people are competing, we decide to celebrate it only with qolo and bread, and if possible t'alla' (Interviewee 4). We can view the church's preoccupation with limiting the amount of food served at the meetings as its way of securing the future existence of religious mahbär.

Prices have increased significantly every year in recent years, making the cost of living and hence the cost of preparing food for a mahbär meeting very high. As a response to these challenges, some mahbär have decided to arrange meetings every other month instead of monthly meetings. Some members 
have vowed to never leave their mahbär despite these difficult economic circumstances. Quitting or even reducing the type of food to be prepared for the regular meetings is considered unacceptable to many because, according to them, this signifies a weak commitment to one's religion.

Members do not discuss their financial hardship because they think that this might dishearten Saint Mary. Some say nothing is more important than celebrating her, even when they are very poor. Surprisingly, when they bring her into their home they get something good. As a result, people have a firm belief.

INTERVIEWEE 15

Most members strongly believe that they have to continue despite the economic difficulties of preparing food for the meetings. This belief indicates the dilemma these members are facing and the difficulty of deciding whether to remain or quit. Others believe that these things will be taken care of: 'You know, even if you prepare only a handful, you will still have leftovers. Since you prepare it in the Saint's name it will always be enough' (Interviewee 5). In addition to providing food for the meetings, which the small fee contributed does not cover, we have seen that the members have extensive social obligations toward members' families. They are expected to participate in weddings, christenings, and funerals in addition to visiting the sick and new mothers after delivery. Since gifts must be provided, all these social obligations are both expensive and very time consuming. Reducing the amount of food or having the meetings every other month does not solve the challenges of the extensive social obligations toward members' families.

We suggest that in times of economic hardship, which include our entire research period, the Orthodox then prioritize iddir. As is the case with many African countries (Tostensen et al. 2001), Ethiopia has a variety of indigenous associations that are diverse in purpose, membership size, and importance in the communities. The association that is the most ubiquitous is iddir, the main function of which is to provide financial and in-kind support to households when a family member dies. This assistance is usually in the form of finances to cover funeral costs. While iddir is a collective insurance for the family as well as the individual, the mahbär is attended more often to strengthen people individually. Mahbär also tend to be a smaller group of approximately twelve members, while iddir may have from twelve to several hundred members (Encyclopaedia Aethiopica vol. 2 2005). Compared to iddir, the membership in religious mahbär seems to be more personal. 


\section{Time Constraints}

Time constraint is a relatively recent challenge that may in time create changes in the associations' practices. People complained that they did not have time to socialize with members of their respective mahbär. 'Earlier people used to help each other. Currently the youngsters do not have time' (Interviewee 3). It has become difficult to visit the sick and socialize with members because people need more time to earn an income for their livelihood.

If forced to prioritize, people will choose to uphold their iddir membership due to its important function in assisting with burials and its function as economic insurance for the whole family. The iddir will pay money to the family of the deceased from the fees that the members have paid over the years. The amount paid out depends on whether it is the main provider or another family member who has died. People may have several iddir as forms of economic insurance, and being forced to terminate one's iddir membership is considered devastating.

\section{Recruiting New Members}

A third challenge is recruiting new members when old ones die or are forced to terminate their membership. Urbanization processes provide neighborhoods with new residents on a regular basis, so how can it be difficult to recruit new members? Members express the challenge as finding someone to trust. Some attribute this to a change in people's values in which they have become more selfish and less caring toward each other. The increased time spent on income-generating activities allows less time to get to know people in the neighborhood, and hence to build relationships of trust. Trust in other members is essential since they trust each other not only with money but also with experiences, thoughts, and feelings. In addition, sections of the educated class and the youth consider membership in religious mahbär as somewhat oldfashioned, and may prefer other ways of socializing and worshipping. In our view, this is one of the most significant reasons for the ritual's decline.

\section{Contextualizing the Changes in Religious Mahbär}

In our view, the modernization of Ethiopian working life, including changes in gender relations, is contributing to the decline of religious mahbär. We propose that following their increased involvement in paid labor and the formal economy, women on the one hand have reduced flexibility regarding their time use, but on the other hand they have more freedom to participate 
in social activities outside the neighborhood. While in earlier times religious mahbär may have been one of the few legitimate opportunities for women to socialize with other women and enjoy themselves, they now have other options such as spending time with workmates and friends. In our opinion women are now in a better position to negotiate their time in relation to their husbands and other family members. Equal rights for women have been legally secured in Article 35 of the Ethiopian Constitution (from 1995) and in the new Family Law (revised in 2000). Awareness about these issues is increasing in the Ethiopian society.

The flexibility of the mahbär allows some of its elements to be transported into different associations. However, the explicitly religious ritual elements seem to be pushed into the background or even lost. We see this in the increased popularity of different kinds of mahbär such as friendship mahbär, family and relative mahbär, schoolmate mahbär, workplace mahbär, and so on. In these new versions of mahbär the complexity of the ritual seems to be reduced or to disappear, retaining only the socializing and network dimensions as well as the regularity of the meetings, preferably once a month. These new mahbär have more flexible rules with fewer regulations and obligations than traditional ones. In this type of mahbär members do not necessarily meet once a month, there is not necessarily a patron saint even though they could have one, at least to signal which day of the month they are to meet, they may meet in a public place, and there are fewer associated social obligations. The main purpose of such mahbär is to facilitate people staying in touch. These associations can be an addition to as well as a substitute for religious mahbär.

The changes in the Ethiopian religious field with the strengthened position of Islam globally as well as other variants of Christianity such as Protestantism, and Pentecostal and other evangelical Christian congregations provides an important context for understanding the changes in religious practices among Orthodox Christians. Offering services on weekday evenings on weekdays can be viewed as one answer to such challenges for the Orthodox Täwahïdo Church, as is preaching and spreading the gospel in the Amharic language rather than only in $G e e^{\prime} z{ }^{26}$ Increased attendance at these services and in religion in general has been observed, including among youth.

Despite the changes, it is interesting to see that some of the social elements are preserved through new kinds of mahbär, while people find new ways of strengthening their religious engagement (i.e., through increased attendance at church services). The religious everyday practice seems to be on the move from the private or semiprivate to the public sphere. This may also be a result of the increased religious competition in Ethiopia, and the need for the Ethiopian Orthodox Täwahïdo Church to exert its presence in a new way. 


\section{Conclusion}

Through empirical analysis we explored religious mahbär as a ritual, its dynamics and main functions, and the challenges it faces in today's urban Ethiopian society. The tsïwwa as a ritual is perhaps mostly characterized by its complexity and flexibility. Since the ritual is practiced quite flexibly in the everyday lives of Ethiopian Orthodox believers, it can be viewed as a cultural toolbox that supports members in different ways adapted to the specific needs of the members. Thus the mahbär benefits both the Church and its members.

Despite its multifunctionality and flexibility, membership in the association and practicing of the ritual is declining. We suggest that this is due to the increased pressure on people's finances and time, in addition to the difficulties of recruiting new members. What this means for mahbär as a ritual remains unclear. Changes in gender relations, modernization processes, and economic hardship are putting increased pressure on women's time. Since women are very important in upholding the ritual, its future seems uncertain. Furthermore, we have seen that people are establishing new kinds of social mahbär with fewer ritual and religious elements, and that the Orthodox Täwahïdo Church's practices seem to be leading to greater attendance at church services.

\section{References $^{27}$}

Abbink, Jan. 2003. 'A Bibliography on Christianity in Ethiopia'. ASC Working Paper 52/2003. Leiden: African Studies Centre.

Alula Pankhurst, and Damen Haile Mariam. 2007. 'The Iddir in Ethiopia. Historical

Development, Social Function, and Potential Role in HIV/AIDS Prevention and Control'. Northeast African Studies, 7.2, 35-57.

Ancel, Stephane. 2005. 'Mahbär et sänbäte: Associations religieuses en Ethiopie'. Aethiopica 8, 95-111.

Aspen, Harald. 1994. 'Spirits, Mediums, and Human Worlds. The Amhara Peasants of the North Ethiopian Highlands and their Traditions of Knowledge'. Unpublished Ph.D. dissertation, University of Trondheim, Trondheim.

Bahiru Zewdie. 2002. A History of Modern Ethiopia 1855-1991 (2nd ed.). Oxford: James Curry.

Bell, Catherine. 1997. Ritual. Perspectives and Dimensions. Oxford: Oxford Univ. Press. Berhanu Gobena. 2000. Amde Haimanot (Amharic). Addis Ababa: Africa Printing Press.

Central Statistical Agency (CSA). 2011. Analytical Report on Population size and Characteristics. Based on 'The 2007 Population and Housing Census of Ethiopia. Results at a Country Level'. Addis Ababa: csA. 
Chaillot, Christine. 2002. The Ethiopian Orthodox Täwahïdo Church Tradition. Paris: Inter-Orthodox Dialogue.

Dessalegn Rahmato. 2008. 'The Voluntary Sector in Ethiopia: Challenges and Future Prospects'. In Taye Assefa and Bahru Zewde (eds.), Civil Society at the Crossroads: Challenges and Prospects in Ethiopia. Addis Ababa: Forum for Social Studies, 81-134.

Elias Teshome. 2008. 'The role of self-help voluntary associations in promoting women's social and economic well-being: The case of women's iddirs in Addis Ketema sub-city, Addis Ababa'. Unpublished ma thesis, Addis Ababa University.

Emebet Mulugeta. 2008. 'Negotiating Poverty: Problems and Coping Strategies of Women in Five Cities of Ethiopia'. In Emebet Mulugeta (ed.), Urban Poverty in Ethiopia: The Economic and Social Adaptations of Women. Addis Ababa: Addis Ababa University Press, 9-72.

Encyclopaedia Aethiopica. 2005. Volume 2. Wiesbaden: Harrassowitz Verlag. Encyclopaedia Aethiopica. 2007. Volume 3. Wiesbaden: Harrassowitz Verlag. Encyclopaedia Aethiopica. 2010. Volume 4. Wiesbaden: Harrassowitz Verlag. Ethiopian Orthodox Church. 1998. 'Yetsïwwa Mahber'. Hamer 5, 8-10 (In Amharic).

Flemmen, Anne Britt. 2008. "They share my happiness and my sadness". Friendship Among Women in Addis Ababa'. In Emebet Mulugeta (ed.), Urban Poverty in Ethiopia. The Economic and Social Adaptations of Women. Addis Ababa: Addis Ababa University Press, 112-163.

Getachew Mequanent. 1998. 'Community Development and the Role of Community Organizations: A Study in Northern Ethiopia'. Canadian Journal of African Studies 32.3, 494-520.

Gilhus, Ingvild, and Lisbeth Mikaelsson. 2001. Nytt blikk på religion. Oslo: Pax Forl (in Norwegian).

Gorgorios. 1982. The History of the Ethiopian Orthodox Church. Addis Ababa: The Ethiopian Orthodox Church Literature Service Section (in Amharic).

Grimes, Ronald L. 2014. The Craft of Ritual Studies. Oxford/New York: Oxford University Press.

Karbo, Tony. 2013. 'Religion and Social Cohesion in Ethiopia'. In International Journal of Peace and Development Studies 4.3, 43-52.

Korten, David C., and Frances F. Korten. 1972. Planned Change in a Traditional Society. Psychological Problems of Modernization in Ethiopia. New York: Preager Publisher.

Levine, Donald. 1965. Wax and Gold. Tradition and Innovation in Ethiopian Culture. Chicago, IL: University of Chicago Press.

Marcus, Cressida. 2001. 'The Production of Patriotic Spirituality: Ethiopian Orthodox Women's Experience of War and Social Crises'. Northeast African Studies 8.3, 179-208.

Marcus, Cressida. 2002. 'In Praise of Women: The Veneration of the Virgin Mary in the Ethiopian Orthodox Church'. Journal of Ethiopian Studies 35.1. 9-26. 
Messay Kebede. 1999. Survival and Modernization. Ethiopia's Enigmatic Present: A Philosophical Discourse. Asmara: The Red Sea Press.

Molvaer, Reidulf K. 1980. Tradition and Change in Ethiopia: Social and Cultural Life as Reflected in Amharic Fictional Literature. Leiden: E.J. Brill.

New Testament, New International Version.

Pankhurst, Richard, and Endreas Eshete. 1958. 'Self-help in Ethiopia'. Ethiopia Observer 2.11, 354-364.

Pankhurst, Helen. 1992. Gender, Development and Identity. An Ethiopian Study. London: Zed Books.

Prouty, Chris, and Eugene Rosenfeld. 1981. The Historical Dictionary of Ethiopia. African Historical Dictionaries 32. London: The Scarecrow Press Inc.

Tostensen, Arne, Inge Tvedten, and Mariken Vaa (eds.). 2001. Associational Life in African Cities. Popular Responses to the Urban Crisis. Stockholm: Nordiska Afrikainstitutet.

Ullendorff, Edward. 1965. The Ethiopians: An Introduction to Country and People. London: Oxford University Press.

Wassie Kebede, and Alice K. Butterfield. 2007. 'Social networks and communication: Evidence of social capital among poor women in Ethiopia'. Unpublished teaching material, School of Social Work, Addis Ababa University.

\section{Notes}

* We would like to extend our profound thanks to Professor Siv Ellen Kraft, UiT The Arctic University of Norway, and to Professor Helen Verran, Charles Darwin University) for their contributions to this article, as well as to the editor and reviewers for their helpful comments.

1 The transliteration of Amharic names and words is based on the system developed by Institute of Ethiopian Studies (IES) and as used in Journal of Ethiopian Studies. There are some modifications; only those diacritical marks available on a standard computer have been used (in line with Aspen 1994). The reader should be informed that there are several ways of spelling Amharic words using the Latin alphabet. There is no coherent practice throughout the texts we have read. For example, iddir can be spelled edir or edder and mahbär is also spelled maheber or mehaber.

2 In the text we use the terms 'religious mahbär' and 'mahbär' interchangeably. Other kinds of mahbär exist in Ethiopia (see also Ancel 2005); when referring to these we specify the kind of mahbär.

3 Included in the Protestant category are Seventh-day Adventist, Pentecost, Lutheran, Baptist, Anglican, Presbyterian, Meserete Kristos, and Mulu Wengel Kale Hiywät'.

4 Religious unions are common among Protestants and have some similarities to mahbär. Pentecostals have Bible study hibret (union or fellowship) for prayer and fellowship. For example, the Muluwengel Church has many forms of hibret consisting of 10 to 20 members. The major ones are: betäsäb hïbrät (any church member above the age of 16) and youth hïbrät 
(from 16 to 29 years). These groups meet every week for two hours in a church member's house in their locality. Furthermore, there are hïbrät consisting of married women and unmarried women (heads of households) who meet monthly and are a kind of women's iddir with spiritual activities added. The hïbrät engages in social activities such as yätamämä (visiting the sick), yäwälädä mätäyäq (vising those who give birth), and läqqso mädräs (visiting families of a deceased).

$5 \quad$ This is in line with the analytical tradition of using ideal types.

6 In Ethiopia the term 'Wz.' (a combination of Woyzärit or W/t. and Woyzäro or W/o.) is used as an equivalent to the English Ms.

This particular mahbär was established to honour Mareyam or Saint Mary, and they therefore hold their meetings on the twenty-first of each month, the date assigned to honor Saint Mary in Ethiopia. Saint Mary is considered a mediator in the Orthodox Täwahïdo Church. For more about the role of Saint Mary see Cressida Marcus 2002.

8 S'ewa refers to the pot used by Ethiopian Orthodox believers to drink t'ela (a local homebrewed beer) or water. It is considered a symbol of unity to drink from the same pot, the s'ewa. The meeting in the religious mahbär is also referred to as 'drinking tsïwwa'. Note that this is not the same as holy water. In this text we use tsiwwa and religious mahbär synonymously.

$9 \quad$ A part of the bread brought to the host of the next mahbär meeting.

10 A person who leads or is in charge of a mahbär. Muse is the Amharic name for Mosesthe leader who led the people from Egypt to Israel.

11 A staple food of Ethiopians mainly made of t'ef, a native plant used to make flour.

12 If no priest is present the bread has to be cut by any male present, even if it is a child.

13 When Marcus writes 'The gan, in which beer is brewed, is ceremoniously transferred from house to house according to the rota by which the feast is prepared in alternate homes' (2001, 196-197), we believe this to be a misunderstanding. The gan is a huge container for brewing tälla. It is not carried around, the tsïwwa is.

14 Many of the traits that our interviewees view as part of the way they practice mahbär is described under sänbäte in Encyclopaedia Aethiopica vol. 4 (2010). The 36 holy women of the 120 family. Kidusan anïst (Holy woman) is originally from Geez. The 72 people who were members of the 120 family that followed Jesus Christ and his teachings while he was living on earth. The Ardits are subordinate to the twelve apostles. A district for which an archbishop is responsible.

18 The official home or seat of the patriarch. It also means the area governed by the patriarch.

19 The highest decision-making body of the Ethiopian Orthodox Täwahïdo Church. It consists of all the archbishops.

20 Birr is the national currency; 100 Ethiopian birr is equivalent to approximately five U.S. dollars.

21 Commemoration of the dead on the fortieth day after the burial.

22 Commemoration of the dead on the eightieth day after the burial.

23 In rural parts of Ethiopia mahbär members often support each other by providing labor. They help elders and female members who are unable to plow, weed, and harvest in time. Unlike mahbär in Addis Ababa, in rural Ethiopia members come from different communities, many walking up to ten kilometers to attend a meeting (Getachew 1998:507-508). 
In more general terms, Mogues (2006 cited in Wassie and Butterfield 2007:1) states, 'In rural areas, the social networks of traditional support systems are used as coping strategies for problems related to drought, such as food shortages and the loss of assets through the death of domestic animals and crop failure'.

24 A study by Emebet (2008) in Addis Ababa found that 19.4 percent of the respondents were members of a mahbär, while 82.6 percent had at least one iddir. As a burial association, iddir is also very important among denominations other than the Orthodox.

25 Tabot is a replica of The Arc of the Covenant or the Tablets of Law, present in every Ethiopian Orthodox Church.

26 Ge'ez is an old Ethiopian Semitic language used in the liturgy of the Ethiopian Orthodox Täwahïdo Church.

27 The references list is written according to Ethiopian academic practice: Ethiopian authors' first names are used for the alphabetical order and non-Ethiopian authors' names are listed according to their surnames. 